\title{
Johannes Hevelius: \\ Polish Seventeenth-Century Brewer and Astronomer
}

\author{
Cecylia Iwaniszewska \\ Institute of Astronomy, N. Copernicus University, \\ P-87-100 Torun, Poland
}

On January 28th, 1987 Polish astronomers commemorated the tercentenary of the death of Johannes Hevelius. Born in 1611 of a rich bourgeois family of Gdansk, a Polish merchant city by the Baltic Sea, he studied law at Leiden. But he soon became more interested in sciences and travelled to London; to Paris, where he knew Mersenne, Gassendi and Boulliaud; to Switzerland; and to Germany. On returning home to Gdansk he had to take over the administration of family properties : breweries, stables, town-houses, but he got considerable help from his wife Catherine Rebeschke whom he married in 1635.

He could then turn his attention entirely to observing celestial bodies, his first observation of an annular solar eclipse made him aware of the poor quality of existing lunar charts. So he devoted himself to systematic observation of our satellite, observing the Moon with home-made telescopes, and himself engraving his drawings of lunar details. The instruments installed on a terrace upon the roofs of three adjoining houses formed his observatory, called STELLABURGUM - City of Stars.

On hearing that Gassendi in Paris had also prepared a moon map, Hevelius sent him a sample of lunar drawings and asked for his opinion. These drawings must have been of a very superior quality, because Gassendi reply enthusiastically : ${ }^{1}$ owe you many thanks for the beautiful drawings (...). You are gifted with such superior eyes that the representation could not be improved upon (...). I urge you to bring to light the Moon description that I had planned". The Moon description was been published in Gdansk in 1647 as "Selenographia" (Selene = Greek goddess of the Moon). The volume contained forty lunar charts at different phases, with details, names, and mountain heights with Hevelius' own method. For over 150 years, the book was the best lunar atlas and had a very high reputation among scientists in France, England and Italy.

Hevelius wanted to follow this with another project - the preparation of an extensive catalogue of star positions. For these observations he prepared a whole set of instruments : quadrants, sextants and octants, solidly made out of wood or brass and richly adorned. His favourites were a 5-ft quadrant and a 6-ft sextant with plain sights. The first part of the catalogue describing methods and instruments was published in 1673 as "Machina Coelestis" part I; the second part of "Machina Coelestis" decribing observations, appeared in 1679, while the "Catalogus Stellarum Fixarum" with 1888 star positions was been published only in 1690, after Hevelius' death. He 
also observed the Sun and planets, decribed and discovered comets, publishing the results in his own printing office after he obtained the necessary permission from the Polish king Jan II Casimir, in 1659. In 1664 he was elected as the one hundred and forty-seventh fellow of the Royal Society of London. After the death of his wife Catherine in 1662, he married, in 1663, Elisabeth Koopman, more than thirty years his junior, who not only took care of the house and family, but acted as faithful assistant to Johannes.

One event disturbed the peaceful years of observation and work : the publication in 1674 of a critique of the accuracy of Hevelius' observations by Robert Hooke. Although the observations of Flamsteed at Greenwich in 1676 (with sextants equipped with telesopes) seemed to agree with those of Hevelius, the Royal Society found it best to send young Edmond Halley to Gdansk in 1679 to examine the local instruments and observations made with them. Halley's tests proved the accuracy and reliability of Gdansk measurements, which was duly reported in the "Royal Society Philosophical Transactions" : "Mr. Hally (!) declares himself abundantly satisfied of the use and certainty of these instruments and observations (...) having seen with his own eyes a multitude of observations (...) with the great brass sextant, again and again repeated, most accurately, and almost incredibly to agree."

A few weeks after Halley's visit a fire destroyed STELLABURGUM; houses, instruments, library, printing office, all was gone; only the unfinished catalogue manuscript was saved. Johannes Hevelius was already aged 68 , but nevertheless he undertook the building of a new observatory. He got the necessary funding from the Polish king Jan III Sobieski, and the French king Louis XIV, bought new instruments (which proved to be of much poorer quality), and finally completed the star catalogue, but did not live long enough to see it printed.

The final volume was printed by Elisabeth together with "Firmamentum Sobiescianum" - an atlas of stars dedicated to king Jan III Sobieski. Hevelius had been preparing this atlas for many years and introduced twelve new constellations, one of them being "Scutum Sobiescianum" - the shield of Sobieski with the coat of arms of the King. The constellation "Scutum" still remains on all sky charts, only the name of the Polish king has been omitted. Another constellation named by Hevelius is "Lynx", so named because it consists of very faint stars that can only be seen by a person having the eyes of a lynx, as was the case with Hevelius himself. Yet another constellation is the "Sextant", named after Hevelius' favourite instrument.

Today very few astronomers seem to know that the great observer Tycho Brahe had a worthy successor, and that there was a Polish brewer on the Baltic Sea who owned the greatest European observatory in the mid-seventeenth century, even before the Paris and Greenwich Observatories came into existence, in 1667 and 1675 respectively.

How could this remarkable Moon observer have foreseen that on the 299th anniversary of his death, astronomers would obtain direct pictures of a far-away planet, and pictures of surface details of the satellites of Uranus, among them of little Miranda, many times smaller than the terrestrial Moon... 